\title{
Rekonstruksi Media Interaktif Berbasis Kartun pada Materi Suhu dan Kalor Kelas XI SMA
}

\author{
Heny Ekawati Haryono \\ Universitas Islam Darul 'Ulum Lamongan \\ e-mail: $\underline{\text { Henny@unisda.ac.id }}$
}

\begin{abstract}
Abstrak
Jenis penelitian ini adalah penelitian pengembangan. Tujuannya untuk menghasilkan produk dan mengetahui kelayakan media interaktif berbasis kartun pada materi suhu dan kalor kelas XI SMA. Pengembangan yang dilakukan menggunakan model prosedural dengan mengadaptasi model pengembangan Borg dan Gall. Instrumen pengumpulan data dalam penelitian ini menggunakan lembar validasi berupa angket (kuesioner) menggunakan skala likert. Analisis data menggunakan teknik analisis deskriptif kualitatif dan kuantitatif. Hasil penelitian berupa produk media pembelajaran interaktif berbasis kartun yang dikemas dalam bentuk CD pembelajaran dan dapat dioperasikan dilaptop atau computer. Hasil validasi menunjukkan bahwa secara keseluruhan media pengembangan valid dan layak untuk digunakan dalam pembelajaran materi suhu dan kalor kelas XI SMA.
\end{abstract}

Kata kunci : Penelitian pengembangan, Model Borg dan Gall, Media interaktif berbasis kartun.

\section{PENDAHULUAN}

Perkembangan Ilmu Pengetahuan dan Teknologi (IPTEK) mengalami perubahan disegala bidang, salah satunya dibidang pendidikan. Penerapan Ilmu Pengetahuan dan Teknologi (IPTEK) dibidang pendidikan mengalami beberapa inovasi dalam pembelajarannya, salah satunya penggunaan media pembelajaran. Menurut Setyorini dkk (2016) media pembelajaran adalah alat untuk menyampaikan informasi sehingga proses pembelajaran dapat berlangsung secara efektif dan efisien. Hal ini juga didukung oleh pendapat Arda (2015) bahwa media pembelajaran dapat membantu proses penyampaian informasi dan memberikan rangsangan berupa pikiran, perasaan, dan perhatian peserta didik sehingga menimbulkan motivasi untuk belajar. Oleh karena itu media pembelajaran sangat penting dalam kegiatan pembelajaran.

Penggunaan media pembelajaran pada proses pembelajaran memiliki dampak yang baik untuk peserta didik. Hal ini didukung hasil penelitian dimana media pembelajaran dapat mempermudah proses pembelajaran (Yulianti dkk, 2018), dan meningkatkan variasi belajar (Sanaky, 2013). Selain itu media pembelajaran membuat peserta didik mudah mengingat dan menyerap materi pembelajaran (Ekayani, 2017), serta dapat mengembangkan keterampilan proses sains (Putra dan Sujarwanto, 2017). Hal ini ditambahkan oleh Husein dkk (2015) bahwa media pembelajaran dapat meningkatkan kemampuan berpikir kritis, meningkatkan efisiensi dalam proses pembelajaran Alwi (2017), mengefektifkan komunikasi antara pendidik dan peserta didik (Setyorini dkk, 2016), dan menumbuhkan kemampuan berpikir kreatif peserta didik (Sudianti dan Shinta, 2018). Oleh karena itu, media pembelajaran dapat mendukung tercapainya tujuan pembelajaran secara efektif dan efisien.

Optimalisasi media pembelajaran di lapangan belum dilaksanakan secara maksimal. Hal ini dibuktikan dari hasil penelitian Sukanta, dkk (2016) bahwa pembelajaran di sekolah masih bersifat konvensial, artinya pembelajaran masih dominan menggunakan metode ceramah, peserta didik cenderung pasif, dan pembelajaran di kelas cenderung membosankan. Hal itu juga dipengaruhi oleh kurangnya kreativitas pendidik dalam pembuatan media pembelajaran (Alwi, 2017). Husein dkk (2015) menyatakan bahwa media pembelajaran di lapangan belum dilaksanakan secara maksimal karena pendidik sering tidak menyiapkan media pembelajaran sehingga peserta didik kurang dalam penguasaan materi. Akibatnya peserta didik belum mampu untuk menguasai materi. Kurang menariknya media pembelajaran juga menyebabkan peserta didik tidak tertarik terhadap materi yang disampaikan sehingga mempengaruhi pemahaman peserta didik terhadap materi tersebut (Ditama, dkk, 2015). Upaya mengatasi permasalahan tersebut digunakan media pembelajaran interaktif. 
https://jurnal.unsulbar.ac.id/index.php/saintifik

Media interaktif merupakan salah satu solusi untuk mengatasi permasalahan di lapangan. Media interaktif adalah media yang berupa audio, gambar, animasi, teks, video yang terdiri dari pembelajaran, peserta didik, dan proses pembelajaran (Tarigan, 2015).

Media interaktif yang akan dikembangkan adalah media interaktif berbasis kartun. Kartun adalah gambar yang berpenampilan lucu dan menarik yang menggambarkan suatu peristiwa (Sukanta dkk, 2017). Kartun digunakan untuk menarik perhatian peserta didik sehingga peserta didik lebih mudah menyerap materi dalam pembelajaran (Fitri dan Agus, 2018). Menurut Atun (2015) media kartun dapat menarik perhatian, mempengaruhi sikap dan tingkah laku peserta didik. Hal ini juga dijelaskan oleh Sukanta dkk (2016) bahwa media kartun dapat memberikan edukatif penanaman moral kehidupan sehari-hari kepada peserta didik.

Media interaktif kartun berpengaruh pada kegiatan pembelajaran. Hal ini didasarkan pada penelitian dari Sukanta dkk (2016), bahwa dengan menggunakan media interaktif berbasis kartun dapat meningkatkan hasil belajar peserta didik. Hal ini juga didukung penelitian dari Atun (2016) bahwa dengan menggunakan media interaktif berbasis kartun peserta didik mampu belajar mandiri. Media interaktif berbasis kartun juga memberikan motivasi kepada peserta didik untuk memunculkan ide-ide, sehingga dapat memahami materi yang dijelaskan oleh pendidik (Fitri dan Agus : 2018).

Berdasarkan penjelasan di atas diharapkan dapat menghasilkan produk berupa media interaktif berbasis kartun dan mengetahui kelayakan media interaktif kartun pada materi suhu dan kalor kelas XI SMA. Selain itu, media interaktif berbasis kartun dapat digunakan sebagai media pendukung peserta didik untuk bisa belajar mandiri. Oleh karena itu, penelitian yang akan dilakukan adalah rekonstruksi media interaktif berbasis kartun pada materi suhu dan kalor kelas XI SMA.

\section{METODE PENELITIAN}

Model penelitian yang digunakan adalah Research and Development (R\&D) atau penelitian pengembangan. Research and Development (R\&D) merupakan metode penelitian yang dilakukan untuk menghasilkan suatu produk tertentu, dan juga menguji keefektifan produk tersebut (Sugiyono, 2012). Pengembangan yang dilakukan menggunakan model prosedural dengan mengadaptasi model pengembangan Borg dan Gall. Uji coba produk meliputi desain uji coba produk. Subjek uji coba terdiri atas ahli materi, ahli media, pendidik, dan peserta didik.

Instrumen pengumpulan data dalam penelitian ini menggunakan lembar validasi berupa angket (kuesioner) menggunakan skala likert yang digunakan untuk mengetahui apakah media interaktif dan instrumen yang telah dirancang valid atau tidak. Analisis data pada penelitian ini adalah menggunakan teknik analisis deskriptif kualitatif dan kuantitatif.

\section{HASIL DAN PEMBAHASAN}

\subsection{Penyajian Data Uji Coba}

Potensi dalam penelitian pengembangan ini adalah rekonstruksi media pembelajaran interaktif berbasis kartun pada materi suhu dan kalor kelas XI SMA Negeri 1 Sukodadi. Potensi pengembangan media tersebut berguna untuk mengaktifkan pembelajaran di kelas pada pembelajaran Fisika, sehingga peserta didik lebih aktif dan tidak merasa bosan. Tahapan ini langsung dilakukan dengan wawancara yang berisi tentang sajian media pembelajaran karena peserta didik cenderung bosan dengan pembelajaran yang menggunakan media berupa buku (LKS).

Tahap pengumpulan data dilakukan untuk memperoleh data awal tentang media interaktif dalam pembelajaran di kelas. Data awal tersebut digunakan sebagai bahan pada tahap selanjutnya yaitu tahap perencanaan. Kegiatan yang dilakukan pada tahap ini meliputi kegiatan wawancara kepada pendidik dan peserta didik. Hasil kegiatan wawancara oleh pendidik diperoleh data bahwa pembelajaran di kelas belum efektif karena peserta didik cenderung pasif dan lebih cepat bosan dengan pembelajaran Fisika. Sehingga media yang dibutuhkan adalah media interaktif yang bertujuan untuk mengaktifkan pembelajaran di kelas.

Setelah dilakukan analisis kebutuhan, langkah selanjutnya adalah desain media. Ada beberapa hal yang dilakukan dalam tahap desain media interaktif berbasis kartun materi suhu dan kalor kelas XI SMA. Langkah-langkah penyusunan desain media pembelajaran ini, diantaranya menyesuaikan standar kompetensi, kompetensi dasar dan indikator Fisika Kelas XI SMA. 
Media interaktif berbasis kartun didesain dalam satu tampilan yang mencakup kompetensi, materi, video praktikum, simulasi, serta latihan soal secara menyeluruh sehingga lebih efisien. Rekonstruksi media ini terdapat 6 menu yaitu menu kompetensi, menu baca aku, menu belajar, menu bermain, menu test, dan menu creator. Tokoh utama dalam media interaktif berbasis kartun ini adalah candle. Berikut halaman awal dari media interaktif berbasis kartun.

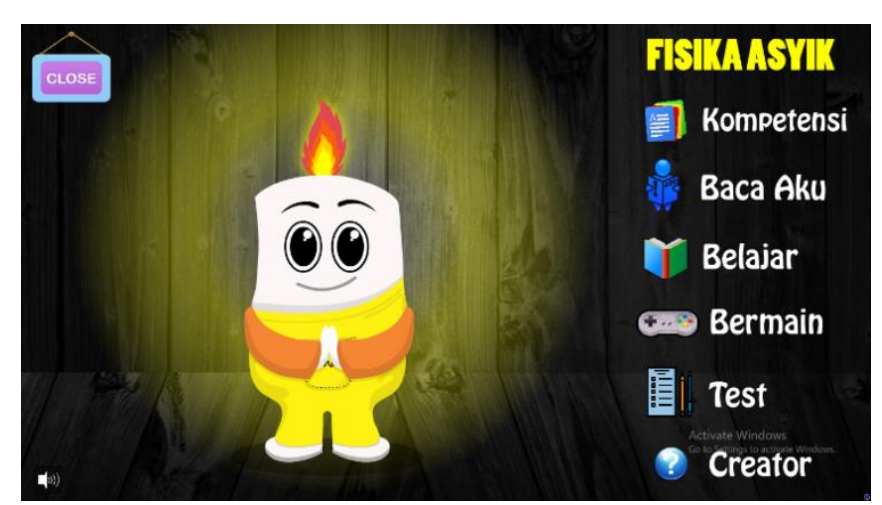

Gambar 1 halaman utama media interaktif berbasis kartun

Deskripsi dari masing-masing menu media interaktif berbasis kartun materi suhu dan kalor adalah sebagai berikut.

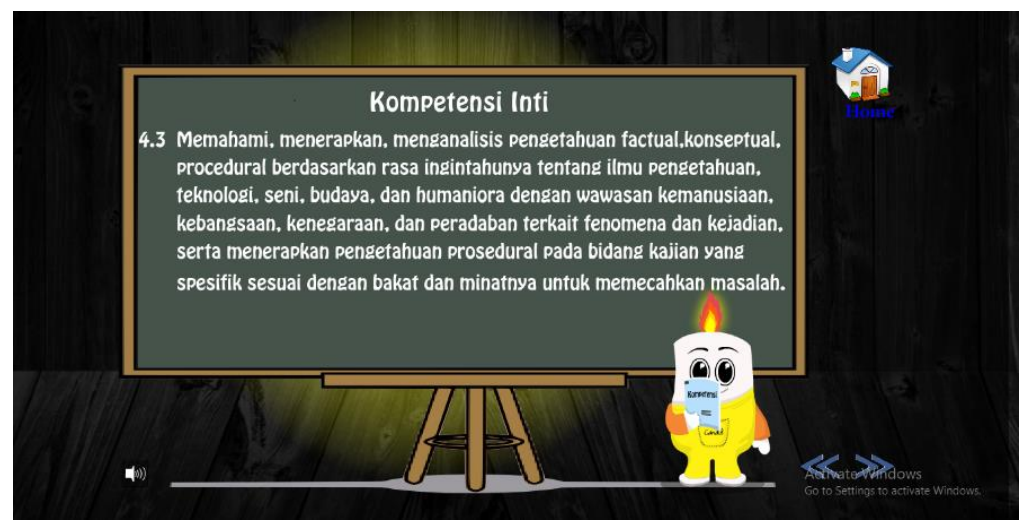

Gambar 2 menu kompetensi media interaktif berbasis kartun

Menu kompetensi berisi tentang kompetensi inti, kompetensi dasar, dan indikator

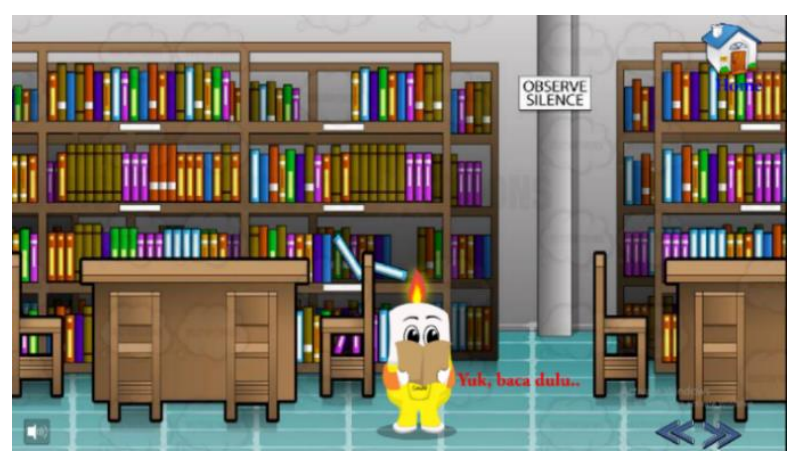

Gambar 3 menu baca aku media interaktif berbasis kartun

Sebelum berlanjut ke menu selanjutnya, peserta didik harus diperlihatkan kemenu baca aku. Menu baca aku adalah menu yang berisi tentang petunjuk penggunaan media interaktif berbasis kartun. Peserta didik harus membaca menu baca aku terlebih dahulu sebelum kemenu berikutnya. 


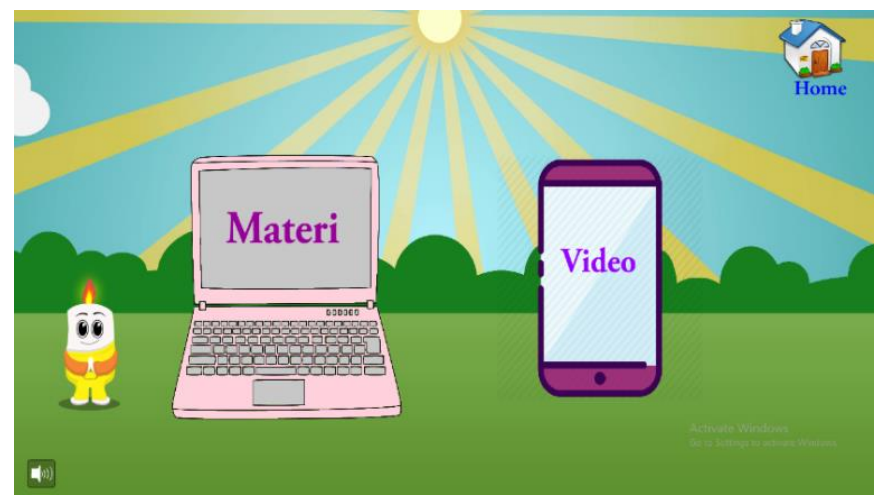

Gambar 4 menu belajar media interaktif berbasis kartun

Menu belajar ini terdiri dari 2 menu yaitu menu materi dan menu video. Di dalam menu materi berisi tentang materi suhu dan kalor yang terdiri dari 5 menu yaitu menu suhu, menu pemuaian, menu kalor, menu perpindahan kalor, dan yang terakhir menu perubahan wujud, disajikan seperti pada gambar berikut.

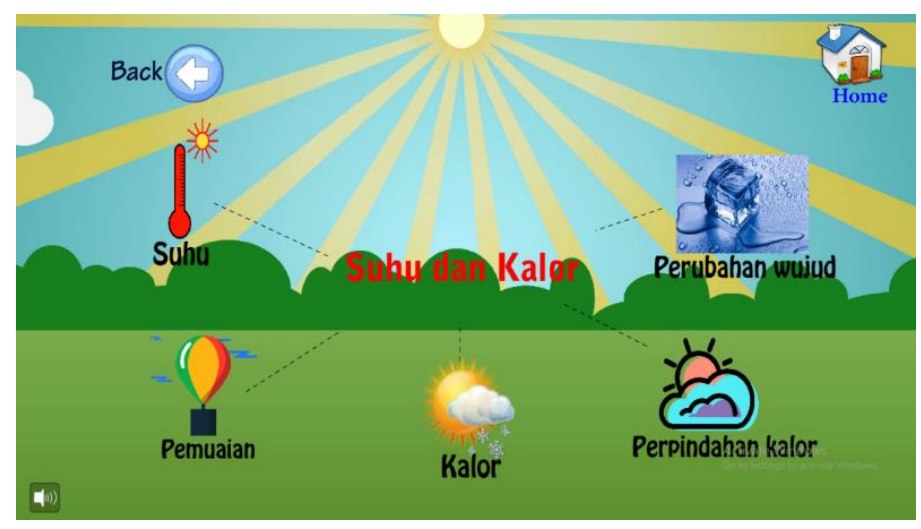

Gambar 5 menu materi media interaktif berbasis kartun

Gambar 5 menu-menu tersebut terdapat pembahasan materi dan beberapa contoh soal agar peserta didik dapat memahami materi. Pada menu belajar juga terdapat menu video seperti pada gambar berikut yang terdiri dari 2 menu.

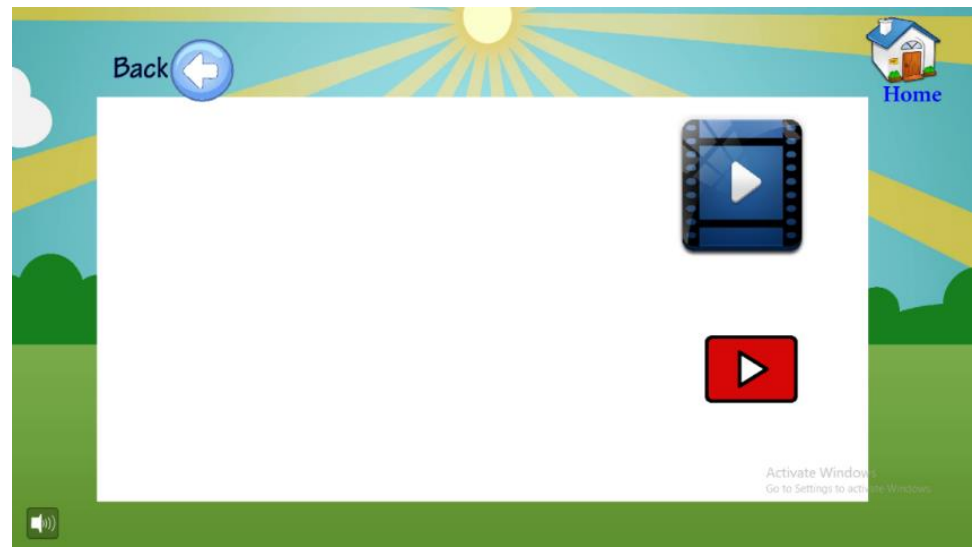

Gambar 6 menu video media interaktif berbasis kartun

Menu video pertama berisi tentang video praktikum 1 yang berjudul praktikum balon tahan api dan video praktikum 2 yang berjudul praktikum air ajaib. 
https://jurnal.unsulbar.ac.id/index.php/saintifik

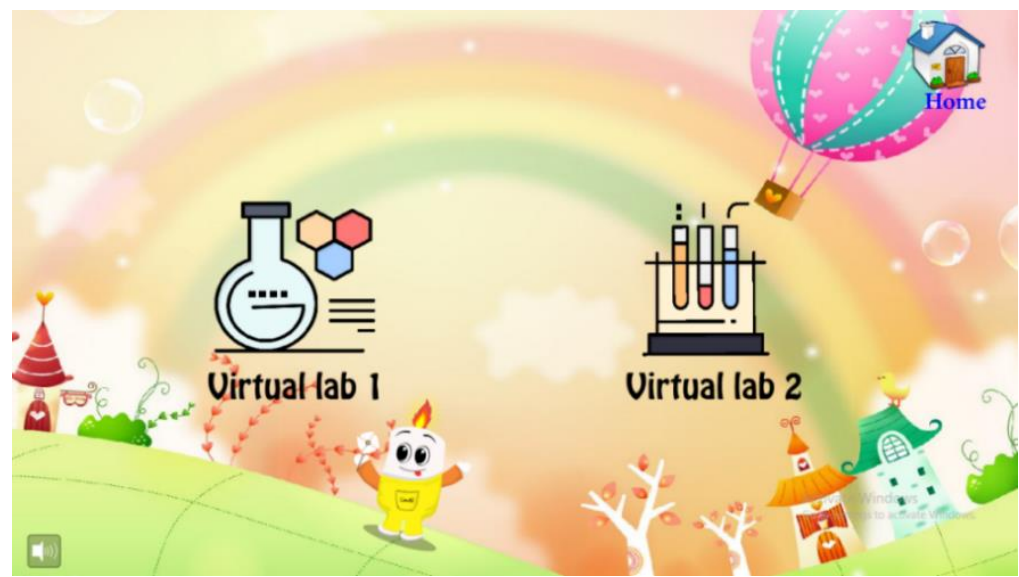

Gambar 7 menu bermain media interaktif berbasis kartun

Menu bermain pada gambar di atas terdiri 2 simulasi virtual lab yang terdiri dari virtual lab 1 dan virtual lab 2 yang berisi tentang simulasi materi suhu dan kalor agar peserta didik lebih memahami materi.

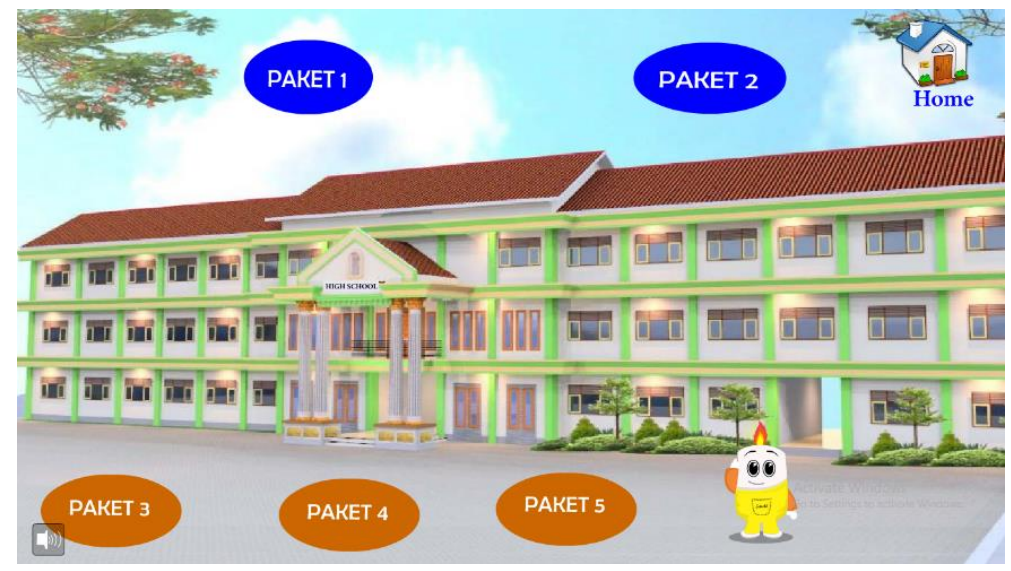

Gambar 8 menu test media interaktif berbasis kartun

Menu test terdiri dari beberapa soal yang harus dikerjakan oleh peserta didik. Soal-soal dibagi dalam 5 paket seperti gambar 8 . Soal tersebut termasuk jenis soal random karena antara paket satu dengan paket lainnya tidak sama sehingga peserta didik dapat berlatih mengerjakan soal-soal dan untuk mengetahui kemampuan penguasaan konsep peserta didik setelah menerima pembelajaran.

\subsection{Hasil Validasi}

\subsubsection{Hasil Validasi Materi}

Data hasil validasi materi disajikan pada tabel di bawah ini :

Tabel 1 Data Hasil Uji Validasi Ahli Materi

\begin{tabular}{|l|l|l|c|c|c|}
\hline No & Aspek Penilaian & \multicolumn{1}{|c|}{ Deskripsi } & $\begin{array}{c}\text { Skor } \\
\text { Ahli } \\
\text { Materi }\end{array}$ & $\begin{array}{c}\text { Jumlah } \\
\text { Skor tiap } \\
\text { Aspek }\end{array}$ & $\begin{array}{c}\text { Jumlah } \\
\text { skor } \\
\text { maksimal }\end{array}$ \\
\hline 1 & Kualitas materi & $\begin{array}{l}\text { Tidak ada aspek indikator } \\
\text { yang menyimpang }\end{array}$ & 5 & & \\
\cline { 3 - 4 } & $\begin{array}{l}\text { Kejelasan isi materi } \\
\text { (termasuk KI, KD, dan } \\
\text { Indikator) }\end{array}$ & 4 & \multirow{2}{*}{19} & 25 \\
\cline { 3 - 4 } & $\begin{array}{l}\text { Uraian isi materi } \\
\text { Kejelasan contoh yang } \\
\text { disertakan }\end{array}$ & 3 & & \\
\hline
\end{tabular}


https://jurnal.unsulbar.ac.id/index.php/saintifik

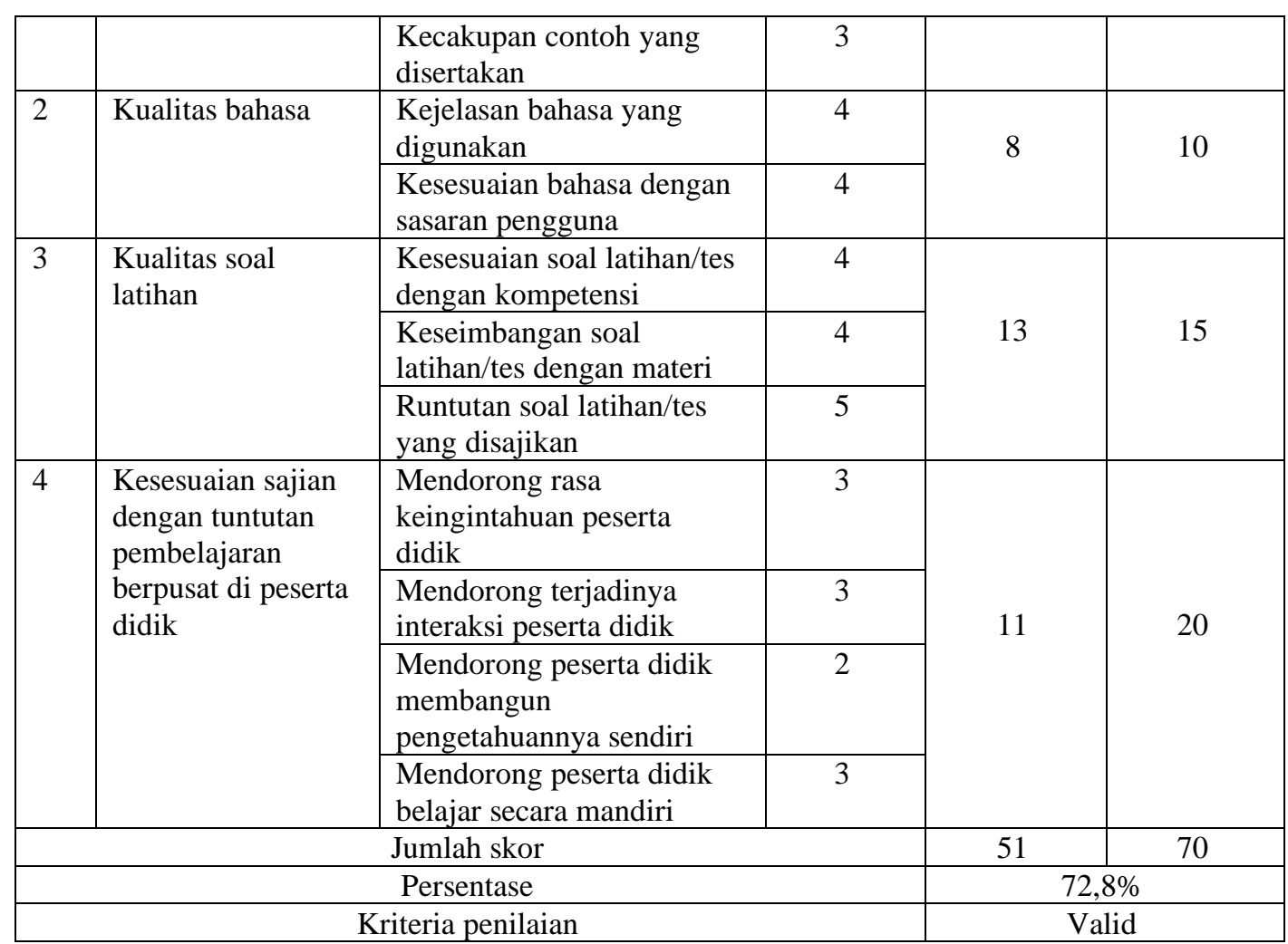

Pada aspek kualitas materi, tidak ada aspek indikator yang menyimpang. Isi materi (termasuk KI,KD, dan Indikator) dan uraian isi materi juga sudah jelas. Pada aspek kualitas bahasa, kejelasan bahasa yang digunakan dan kesesuaian bahasa dengan sasaran pengguna sudah layak digunakan di media interaktif berbasis kartun. Pada aspek kualitas soal latihan, kesesuaian soal latihan/tes dengan kompetensi dan keseimbangan soal latihan/tes dengan materi sudah baik serta soal latihan/tes yang disajikan sudah sangat runtut.

Aspek kesesuaian sajian dengan tuntutan pembelajaran berpusat pada peserta didik. Pada aspek ini, media belum mendorong rasa keingintahuan peserta didik, belum mendorong terjadinya interaksi antar peserta didik, belum membangun pengetahuannya sendiri, dan mendorong peserta didik belajar secara mandiri dengan cara memberikan pertanyaan menarik tentang kehidupan sehari-hari sesuai dengan materi suhu dan kalor, memberikan bahan diskusi kelompok, memberikan tugas proyek, dan membuat beberapa soal latihan yang lebih bervariasi.

Dilakukan perhitungan untuk keseluruhan item/aspek berdasarkan data ahli materi.

$$
\begin{aligned}
& \text { persentase ideal }(\%)=\frac{\text { skor hasil penelitian }}{\text { skor maksimal ideal }} \times 100 \% \\
& =\frac{51}{70} \times 100 \% \\
& =72,8 \%
\end{aligned}
$$

Berdasarkan kriteria tingkat kelayakan, maka materi yang ada pada media pembelajaran interaktif berbasis kartun pada materi suhu dan kalor kelas XI SMA/MA dalam kualifikasi valid digunakan untuk media pembelajaran peserta didik dengan rentang skor antara 60,0\% - 81,0\%. Hal ini didukung oleh penelitian Riyana (2007) bahwa media interaktif berbasis kartun layak digunakan karena media interaktif memberikan sarana belajar berupa materi, metode, batasan-batasan, dan cara mengevaluasi yang dirancang secara sistematis dan menarik untuk mendukung pembelajaran menjadi lebih efektif dan efisien. 
https://jurnal.unsulbar.ac.id/index.php/saintifik

\subsubsection{Hasil Validasi Media}

Data hasil uji validasi ahli media diperoleh dari 1 orang dosen Fakultas Keguruan dan Ilmu Pendidikan Universitas Islam Darul 'Ulum Lamongan. Ahli media melakukan validasi sebanyak satu kali, sesuai data validasi yang disajikan dalam tabel berikut :

Tabel 2 Data Hasil Uji Validasi Ahli Media

\begin{tabular}{|c|c|c|c|c|c|}
\hline No & Aspek Penilaian & Deskripsi & $\begin{array}{c}\text { Skor } \\
\text { Ahli } \\
\text { Materi }\end{array}$ & $\begin{array}{l}\text { Jumlah } \\
\text { Skor tiap } \\
\text { Aspek } \\
\end{array}$ & $\begin{array}{c}\text { Jumlah } \\
\text { skor } \\
\text { maksimal }\end{array}$ \\
\hline \multirow[t]{3}{*}{1} & \multirow[t]{3}{*}{ Kualitas umum } & $\begin{array}{l}\text { Kesesuaian media } \\
\text { dengan materi suhu dan } \\
\text { kalor }\end{array}$ & 5 & \multirow[t]{3}{*}{12} & \multirow[t]{3}{*}{15} \\
\hline & & $\begin{array}{l}\text { Kesesuaian pemilihan } \\
\text { animasi dengan materi }\end{array}$ & 3 & & \\
\hline & & $\begin{array}{l}\text { Keteraturan dan } \\
\text { konsistensi tampilan } \\
\text { tombol }\end{array}$ & 4 & & \\
\hline \multirow[t]{4}{*}{2} & \multirow[t]{4}{*}{ Kualitas khusus } & $\begin{array}{l}\text { Tata letak teks, gambar, } \\
\text { dan animasi }\end{array}$ & 4 & \multirow[t]{4}{*}{17} & \multirow[t]{4}{*}{20} \\
\hline & & $\begin{array}{l}\text { Kesesuaian pemilihan } \\
\text { ukuran dan jenis ukuran } \\
\text { (font) }\end{array}$ & 4 & & \\
\hline & & $\begin{array}{l}\text { Kesesuaian pemilihan } \\
\text { baground }\end{array}$ & 5 & & \\
\hline & & Kesesuaian warna & 4 & & \\
\hline \multirow[t]{5}{*}{3} & \multirow[t]{5}{*}{ Penyajian media } & $\begin{array}{l}\text { Tampilan media yang } \\
\text { menarik }\end{array}$ & 4 & \multirow[t]{5}{*}{20} & \multirow[t]{5}{*}{25} \\
\hline & & $\begin{array}{l}\text { Sajian animasi yang } \\
\text { menarik }\end{array}$ & 3 & & \\
\hline & & $\begin{array}{l}\text { Diberi judul/keterangan } \\
\text { media }\end{array}$ & 4 & & \\
\hline & & $\begin{array}{l}\text { Terdapat cara } \\
\text { penggunaan media }\end{array}$ & 4 & & \\
\hline & & $\begin{array}{l}\text { Mampu mendorong } \\
\text { peserta didik belajar } \\
\text { secara mandiri }\end{array}$ & 5 & & \\
\hline \multicolumn{4}{|c|}{ Jumlah skor } & 49 & 60 \\
\hline \multicolumn{4}{|c|}{ Persentase } & \multicolumn{2}{|c|}{81,6} \\
\hline \multicolumn{4}{|c|}{ Kriteria penilaian } & \multicolumn{2}{|c|}{ Sangat Valid } \\
\hline
\end{tabular}

Pada aspek penilaian kualitas umum, media interaktif berbasis kartun ini sesuai dengan materi suhu dan kalor. Pada tampilan tombol sangat teratur dan konsisten sesuai dengan tempat yang disediakan sehingga tombol tertata rapi. Tapi pada pemilihan animasi kurang sesuai karena pada materi perubahan wujud cair ke padat animasi candle melihat ke belakang jadi seolah-olah animasi candle membakar kulkas. Jadi untuk memperbaiki, animasi candle harus menghadap ke depan.

Pada aspek penilaian kualitas khusus, tata letak penulisan, gambar, dan animasi sudah sangat baik. Pada pemilihan ukuran dan jenis ukuran (font) juga sangat baik. Pemilihan background dan warna juga sangat sesuai. Aspek penyajian media, tampilan media sudah menarik tapi ada beberapa animasi yang perlu diperbaiki karena kurang menarik. Animasi yang kurang menarik adalah animasi yang kurang sesuai dengan materi perubahan wujud zat cair ke padat yang sudah dalam penjelasan di atas. Pada media ini juga sudah diberi keterangan/judul untuk memudahkan peserta didik belajar dan juga sudah disertai cara penggunaan media agar peserta didik mengetahui cara penggunaannya sebelum menggunakan media ini. Media ini juga mampu 
mendorong peserta didik belajar secara mandiri. Perhitungan untuk keseluruhan item/aspek sebagai berikut.

$$
\begin{aligned}
& \text { Persentase ideal }(\%)=\frac{\text { skor hasil penelitian }}{\text { skor maksimal ideal }} \times 100 \% \\
& =\frac{49}{60} \times 100 \% \\
& =81,6 \%
\end{aligned}
$$

Berdasarkan kriteria tingkat kelayakan, maka materi yang ada pada media pembelajaran interaktif berbasis kartun pada materi suhu dan kalor kelas XI SMA/MA dalam kualifikasi sangat valid digunakan untuk media pembelajaran peserta didik dengan rentang skor nilai $81,0 \%-100,0 \%$. Hal ini didukung oleh penelitian Supriadi (2008) bahwa penggunaan media kartun dalam pembelajaran matematika sangat valid digunakan sebagai media pembelajaran. Hasil penelitian Sukanta dkk (2016) juga menunjukkan bahwa media interaktif berbasis kartun dapat memberikan edukatif penanaman moral kepada peserta didik.

\subsubsection{Hasil Validasi Pendidik}

Data hasil uji validasi ahli media diperoleh dari 1 orang pendidik di SMA Negeri 1 Sukodadi. Pendidik

\begin{tabular}{|c|c|c|c|c|c|}
\hline No & Aspek Penilaian & Deskripsi & $\begin{array}{c}\text { Skor } \\
\text { Ahli } \\
\text { Materi }\end{array}$ & $\begin{array}{l}\text { Jumlah } \\
\text { Skor tiap } \\
\text { Aspek }\end{array}$ & $\begin{array}{l}\text { Jumlah } \\
\text { skor } \\
\text { maksimal }\end{array}$ \\
\hline \multirow[t]{3}{*}{1} & \multirow[t]{3}{*}{ Pemrograman } & $\begin{array}{l}\text { Kemudahan pemakaian } \\
\text { media }\end{array}$ & 5 & \multirow[t]{3}{*}{15} & \multirow[t]{3}{*}{15} \\
\hline & & $\begin{array}{l}\text { Kemudahan memilih } \\
\text { menu progam }\end{array}$ & 5 & & \\
\hline & & $\begin{array}{l}\text { Kemudahan masuk dan } \\
\text { keluar dari progam }\end{array}$ & 5 & & \\
\hline \multirow[t]{5}{*}{2} & \multirow[t]{5}{*}{ Isi } & $\begin{array}{l}\text { Kejelasan bahasa yang } \\
\text { digunakan }\end{array}$ & 4 & \multirow[t]{5}{*}{22} & \multirow[t]{5}{*}{25} \\
\hline & & $\begin{array}{l}\text { Tidak ada kata/kalimat } \\
\text { yang menyimpang }\end{array}$ & 4 & & \\
\hline & & $\begin{array}{l}\text { Melalui media ini } \\
\text { peserta didik mampu } \\
\text { untuk memahami materi } \\
\text { suhu dan kalor }\end{array}$ & 4 & & \\
\hline & & $\begin{array}{l}\text { Bahasa yang digunakan } \\
\text { mudah dipahami }\end{array}$ & 5 & & \\
\hline & & $\begin{array}{l}\text { Soal evaluasi (latihan) } \\
\text { sesuai dengan materi } \\
\text { suhu dan kalor }\end{array}$ & 5 & & \\
\hline \multirow[t]{5}{*}{3} & \multirow[t]{5}{*}{ Tampilan } & $\begin{array}{l}\text { Tata letak teks dan } \\
\text { gambar }\end{array}$ & 5 & \multirow[t]{5}{*}{30} & \multirow[t]{5}{*}{30} \\
\hline & & Kesesuaian background & 5 & & \\
\hline & & Kesesuaian warna & 5 & & \\
\hline & & $\begin{array}{l}\text { Kesesuaian pemilihan } \\
\text { ukuran dan jenis huruf }\end{array}$ & 5 & & \\
\hline & & $\begin{array}{l}\text { Kesesuaian gambar } \\
\text { animasi yang disajikan }\end{array}$ & 5 & & \\
\hline
\end{tabular}
melakukan validasi sebanyak satu kali, sesuai data validasi yang disajikan dalam berikut.

Tabel 3 Data Hasil Uji Validasi Pendidik 
https://jurnal.unsulbar.ac.id/index.php/saintifik

\begin{tabular}{|c|c|c|c|c|c|}
\hline & & $\begin{array}{l}\text { Kemenarikan gambar } \\
\text { animasi yang disajikan }\end{array}$ & 5 & & \\
\hline \multirow[t]{3}{*}{4} & \multirow{3}{*}{$\begin{array}{l}\text { Kesesuaian } \\
\text { sajian dengan } \\
\text { tuntutan } \\
\text { pembelajaran } \\
\text { berpusat di } \\
\text { peserta didik }\end{array}$} & $\begin{array}{l}\text { Mendorong rasa } \\
\text { keingintahuan peserta } \\
\text { didik }\end{array}$ & 5 & \multirow[t]{3}{*}{15} & \multirow[t]{3}{*}{15} \\
\hline & & $\begin{array}{l}\text { Mendorong terjadinya } \\
\text { interaksi peserta didik }\end{array}$ & 5 & & \\
\hline & & $\begin{array}{l}\text { Mendorong peserta } \\
\text { didik belajar secara } \\
\text { mandiri }\end{array}$ & 5 & & \\
\hline \multicolumn{4}{|c|}{ Jumlah skor } & 82 & 85 \\
\hline \multicolumn{4}{|c|}{ Persentase } & \multicolumn{2}{|c|}{$96,4 \%$} \\
\hline & \multicolumn{3}{|c|}{ Kriteria penilaian } & \multicolumn{2}{|c|}{ Valid } \\
\hline
\end{tabular}

Pada aspek penilaian pemrograman, media ini sangat mudah digunakan, untuk memilih menu progam juga sangat mudah, dan pada menu keluar masuk juga sangat mudah. Pada aspek isi, kejelasan bahasa yang digunakan juga sudah jelas tapi masih beberapa bahasa yang perlu diperbaiki karena kurang bisa dipahami, misalnya pada contoh perubahan wujud menyublim adalah mengeluarkan es dari dalam kulkas kemudian didiamkan beberapa saat, akan mengeluarkan uap air. Pada contoh tersebut kalimat yang digunakan kurang dipahami, perlu diperbaiki agar peserta didik lebih memahami contohnya. Dan juga tidak ada kata/kalimat yang menyimpang hanya ada beberapa kata yang terselip misalnya ada kata yang terkena tangan dari animasi candle. Hal ini menyebabkan perlu diperbaiki lagi. Melalui media ini peserta didik mampu untuk memahami materi suhu dan kalor karena memiliki beberapa soal evaluasi (latihan) sesuai dengan materi yaitu suhu dan kalor.

Pada aspek tampilan sudah sangat layak ditampilkan dalam media interaktif dalam pembelajaran fisika materi suhu dan kalor karena penempatan tata letak penulisan dan gambar sudah baik, background yang digunakan sudah sesuai, warna yang digunakan juga sesuai, pemilihan ukuran dan jenis huruf juga sudah sesuai, pada gambar animasi juga sangat sesuai dengan materi suhu dan kalor, dan gambar animasi yang disajikan sangat menarik membuat peserta didik tidak cepat bosan dalam pembelajaran Fisika materi suhu dan kalor.

Aspek kesesuaian sajian dengan tuntutan pembelajaran peserta didik, media interaktif berbasis kartun ini mampu mendorong rasa keingintahuan peserta didik, mendorong terjadinya interaksi, dan juga mendorong peserta didik belajar secara mandiri. Perhitungan untuk keseluruhan item/aspek sebagai berikut :

$$
\begin{array}{r}
\text { Persentase ideal }(\%)=\frac{\text { skor hasil penelitian }}{\text { skor maksimal ideal }} \times 100 \% \\
=\frac{82}{85} \times 100 \% \\
=96,4 \%
\end{array}
$$

Berdasarkan kriteria tingkat kelayakan, maka media pembelajaran interaktif berbasis kartun pada materi suhu dan kalor kelas XI SMA dalam kualifikasi sangat valid digunakan untuk media pembelajaran peserta didik dengan rentang skor 81,0\% - 100,0\%. Hal ini didukung oleh penelitian Atun (2016) bahwa bahwa media interaktif berbasis kartun valid dan layak digunakan sebagai media pembelajaran karena mampu membuat peserta didik belajar mandiri dan berpikir lebih kritis.

\subsubsection{Hasil Uji Coba Terbatas (Peserta didik)}

Uji coba peserta didik dilakukan setelah mendapatkan hasil yang valid terhadap uji coba yang telah dilakukan oleh ahli materi, ahli media, dan pendidik. Uji coba peserta didik ini dilakukan sebanyak 30 peserta didik yang terdiri dari kelas XI SMA Negeri 1 Sukodadi. Instrumen angket oleh peserta didik terdiri dari 4 aspek yaitu aspek pemrograman, aspek isi, aspek tampilan, dan aspek kesesuaian sajian dengan tuntutan 
https://jurnal.unsulbar.ac.id/index.php/saintifik

pembelajaran peserta didik. Data hasil uji coba peserta didik dapat dilihat pada tabel berikut.

Tabel 4 Data Hasil Uji Coba Terbatas (Peserta didik)

\begin{tabular}{|c|c|c|c|c|c|}
\hline No & Aspek Penilaian & Deskripsi & $\begin{array}{l}\text { Rata-rata } \\
\text { uji coba } 30 \\
\text { peserta } \\
\text { didik }\end{array}$ & $\begin{array}{l}\text { Jumlah } \\
\text { Skor } \\
\text { tiap } \\
\text { Aspek }\end{array}$ & $\begin{array}{l}\text { Jumlah } \\
\text { skor } \\
\text { maksimal }\end{array}$ \\
\hline \multirow[t]{3}{*}{1} & \multirow[t]{3}{*}{ Pemrograman } & $\begin{array}{l}\text { Kemudahan pemakaian } \\
\text { media }\end{array}$ & 4,6 & \multirow[t]{3}{*}{13,9} & \multirow[t]{3}{*}{15} \\
\hline & & $\begin{array}{l}\text { Kemudahan memilih menu } \\
\text { progam }\end{array}$ & 4,6 & & \\
\hline & & $\begin{array}{l}\text { Kemudahan masuk dan } \\
\text { keluar dari progam }\end{array}$ & 4,7 & & \\
\hline \multirow[t]{5}{*}{2} & \multirow[t]{5}{*}{ Isi } & $\begin{array}{l}\text { Kejelasan bahasa yang } \\
\text { digunakan }\end{array}$ & 4,6 & \multirow[t]{5}{*}{23,6} & \multirow[t]{5}{*}{25} \\
\hline & & $\begin{array}{l}\text { Tidak ada kata/kalimat yang } \\
\text { menyimpang }\end{array}$ & 4,8 & & \\
\hline & & $\begin{array}{l}\text { Melalui media ini peserta } \\
\text { didik mampu untuk } \\
\text { memahami materi suhu dan } \\
\text { kalor }\end{array}$ & 4,6 & & \\
\hline & & $\begin{array}{l}\text { Bahasa yang digunakan } \\
\text { mudah dipahami }\end{array}$ & 4,8 & & \\
\hline & & $\begin{array}{l}\text { Soal evaluasi (latihan) sesuai } \\
\text { dengan materi suhu dan kalor }\end{array}$ & 4,8 & & \\
\hline \multirow[t]{6}{*}{3} & \multirow[t]{6}{*}{ Tampilan } & Tata letak teks dan gambar & 4,7 & \multirow[t]{6}{*}{27,9} & \multirow[t]{6}{*}{30} \\
\hline & & Kesesuaian baground & 4,6 & & \\
\hline & & Kesesuaian warna & 4,6 & & \\
\hline & & $\begin{array}{l}\text { Kesesuaian pemilihan } \\
\text { ukuran dan jenis huruf }\end{array}$ & 4,6 & & \\
\hline & & $\begin{array}{l}\text { Kesesuaian gambar animasi } \\
\text { yang disajikan }\end{array}$ & 4,7 & & \\
\hline & & $\begin{array}{l}\text { Kemenarikan gambar } \\
\text { animasi yang disajikan }\end{array}$ & 4,7 & & \\
\hline \multirow[t]{4}{*}{4} & \multirow{4}{*}{$\begin{array}{l}\text { Kesesuaian sajian } \\
\text { dengan tuntutan } \\
\text { pembelajaran } \\
\text { berpusat di } \\
\text { peserta didik }\end{array}$} & $\begin{array}{l}\text { Mendorong rasa } \\
\text { keingintahuan peserta didik }\end{array}$ & 4,6 & \multirow[t]{4}{*}{17,7} & \multirow[t]{4}{*}{20} \\
\hline & & $\begin{array}{l}\text { Mendorong peserta didik } \\
\text { belajar secara mandiri }\end{array}$ & 4,6 & & \\
\hline & & $\begin{array}{l}\text { Saya lebih senang } \\
\text { suhu dan kalor } \\
\text { menggunakan buku }\end{array}$ & 3,8 & & \\
\hline & & $\begin{array}{l}\text { Saya lebih senang belajar } \\
\text { suhu dan kalor menggunakan } \\
\text { media interaktif berbasis } \\
\text { kartun ini }\end{array}$ & 4,7 & & \\
\hline \multicolumn{4}{|c|}{ Jumlah skor } & 83,1 & 90 \\
\hline \multicolumn{4}{|c|}{ Persentase } & \multicolumn{2}{|l|}{$92,3 \%$} \\
\hline \multicolumn{4}{|c|}{ Kriteria persentase } & \multicolumn{2}{|l|}{ Valid } \\
\hline
\end{tabular}

Pada aspek penilaian pemrograman, media ini sangat mudah digunakan, untuk memilih menu progam juga sangat mudah, dan pada menu keluar masuk juga sangat memudahkan peserta didik untuk belajar. Pada aspek isi, kejelasan bahasa yang digunakan juga mudah dipahami, tidak ada kata/kalimat yang menyimpang. Melalui media ini peserta didik mampu untuk memahami materi suhu dan kalor karena memiliki beberapa soal evaluasi (latihan) sesuai dengan materi yaitu suhu dan kalor.

Pada aspek tampilan, media interaktif ini sudah sangat layak ditampilkan dalam pembelajaran karena 
tata letak teks dan gambar, background, warna, pemilihan ukuran dan jenis huruf sudah sangat tertata rapi dan bagus serta gambar animasi yang disajikan juga sesuai dengan materi dan sangat menarik.

Aspek kesesuaian sajian dengan tuntutan pembelajaran peserta didik, media interaktif berbasis kartun ini mampu mendorong rasa keingintahuan peserta didik, dan juga mendorong peserta didik belajar secara mandiri. Sebagian besar peserta didik menyukai media ini karena dapat membantu dalam memahami materi suhu dan kalor kelas XI SMA. Perhitungan untuk keseluruhan item/aspek sebagai berikut :

$$
\begin{aligned}
& \text { Persentase ideal }(\%)=\frac{\text { skor hasil penelitian }}{\text { skor maksimal ideal }} \times 100 \% \\
& =\frac{83,1}{90} \times 100 \% \\
& =92,3 \%
\end{aligned}
$$

Berdasarkan kriteria tingkat kelayakan, maka media pembelajaran interaktif berbasis kartun pada materi suhu dan kalor kelas XI SMA/MA dalam kualifikasi sangat valid digunakan untuk media pembelajaran peserta didik dengan rentang skor $81,0 \%-100,0 \%$. Hal ini didukung oleh penelitian Fitri dan Agus (2018) bahwa media interaktif berbasis kartun sangat valid dan layak digunakan dalam pembelajaran sehari-hari karena memberikan motivasi kepada peserta didik untuk memunculkan ide-ide sehingga dapat memahami materi yang dijelaskan oleh pendidik.

\subsection{Revisi Produk}

\begin{tabular}{|c|c|c|c|}
\hline No & $\begin{array}{c}\text { Uji } \\
\text { Coba }\end{array}$ & Bagian yang perlu direvisi & Bagian yang telah direvisi \\
\hline 1. & $\begin{array}{l}\text { Ahli } \\
\text { materi }\end{array}$ & $\begin{array}{l}\text { a. Sesuaikan contoh pada } \\
\text { bagian pemuaian, } \\
\text { menyublim, konveksi, dan } \\
\text { mengkristal } \\
\text { b. Contoh konduksi kurang } \\
\text { jelas } \\
\text { c. Virtual lab } 1 \text { tidak bisa } \\
\text { dibuka tanpa menggunakan } \\
\text { progam adobe flash } \\
\text { d. Air menguap menjadi uap } \\
\text { air bukan menjadi asap } \\
\text { e. Beberapa button kurang } \\
\text { menonjol sehingga bisa } \\
\text { menimbulkan kebingungan } \\
\text { misalnya button "back to } \\
\text { materi" }\end{array}$ & $\begin{array}{l}\text { a. Dalam materi pemuaian, } \\
\text { menyublim, konveksi, } \\
\text { dan mengkristal sudah } \\
\text { disesuaikan dengan } \\
\text { contoh } \\
\text { b. Contoh konduksi sudah } \\
\text { diperjelas } \\
\text { c. Virtual lab } 1 \text { sudah bisa } \\
\text { digunakan } \\
\text { d. Sudah diperbaiki yaitu air } \\
\text { menguap menjadi uap air bukan } \\
\text { menjadi asap } \\
\text { e. Sudah diberi cara penggunaan } \\
\text { media. Jadi sebelum ke menu } \\
\text { belajar harus ke menu } \\
\text { "baca aku" terlebih dahulu }\end{array}$ \\
\hline
\end{tabular}

Revisi produk dilakukan berdasarkan ahli materi, media, dan pendidik disajikan pada tabel berikut.

Tabel 5 Revisi dari Ahli Materi, Media, dan Pendidik 
https://jurnal.unsulbar.ac.id/index.php/saintifik

\begin{tabular}{|c|c|c|c|}
\hline 2. & $\begin{array}{l}\text { Ahli } \\
\text { media }\end{array}$ & \begin{tabular}{|l} 
a. \\
Pada materi perubahan \\
wujud cair ke padat \\
hilangkan gambar candle \\
(boleh tapi tanpa api atau \\
candle menghadap ke \\
depan) \\
b. Beri suara (dubing) pada \\
materi video
\end{tabular} & $\begin{array}{l}\text { b. Pada materi video sudah diberi } \\
\text { dubing }\end{array}$ \\
\hline 3. & Pendidik & 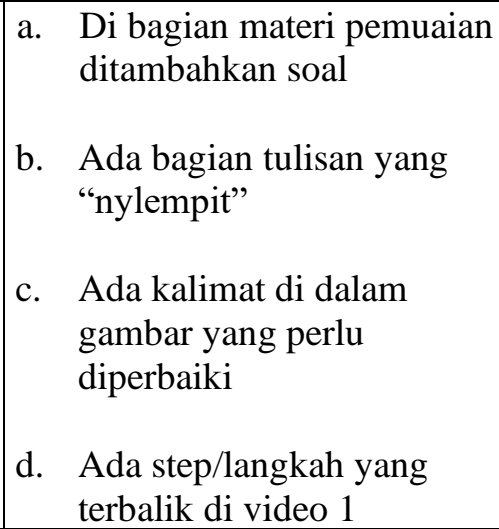 & $\begin{array}{l}\text { a. Sudah ditambahkan soal pada } \\
\text { materi pemuaian } \\
\text { b. Sudah diperbaiki untuk beberapa } \\
\text { tulisan yang "nylempit" } \\
\text { c. Kalimat dalam gambar sudah } \\
\text { diperbaiki } \\
\text { d. Step/langkah di video } \\
\text { sudah diperbaiki }\end{array}$ \\
\hline
\end{tabular}

\section{KESIMPULAN}

Berdasarkan hasil kajian produk yang didasarkan dengan landasan teori dan pemanfaatannya, dapat dinyatakan bahwa media interaktif berbasis kartun memiliki kelebihan dan kekurangan. Kelebihan dalam media interaktif berbasis kartun pada materi suhu dan kalor kelas XI SMA adalah 1) Media interaktif berbasis kartun dapat menjadi media pendukung peserta didik untuk bisa belajar mandiri, 2) Media interaktif berbasis kartun dapat digunakan kapanpun, 3) Media interaktif berbasis kartun dapat membantu peserta didik bersemangat belajar karena tampilannya yang menarik dan mendukung pembelajaran menjadi lebih efektif dan efisien, 4) Media interaktif berbasis kartun ini dilengkapi cara penggunaan media agar pendidik dan peserta didik lebih mudah dalam menggunakan, 5) Media interaktif berbasis kartun disertai dengan video praktikum agar peserta didik lebih memahami materi suhu dan kalor, 6) media interaktif berbasis kartun disertai dengan simulasi (virtual lab) yang memudahkan peserta didik untuk belajar, 7) Media interaktif berbasis kartun dapat memberikan umpan balik (feedback) berupa nilai kepada peserta didik setelah mengerjakan test.

Media interaktif berbasis kartun pada materi suhu dan kalor juga memiliki kekurangan yaitu 1) Media ini dikembangkan melalui laptop atau komputer maka pendidik dan peserta didik juga perlu memiliki alat tersebut, 2) Umpan balik (feedback) yang diterima peserta didik kurang beragam, dan 3) Ada beberapa laptop atau komputer ketika membuka menu virtual lab tidak bisa digunakan. 
https://jurnal.unsulbar.ac.id/index.php/saintifik

Alwi, S. 2017. Problematika Guru dalam Pengembangan Media Pembelajaran Jurnal- Jurnal Ilmu Pendidikan (Itqan), Vol. 8, No.2.

Arda, Saehana, \& Darsikim. 2015. Pengembangan Media Interaktif Berbasis Komputer untuk Siswa SMP Kelas VIII. E-Jurnal Mitra Sains, Vol. 3, No. 1

Atun. S.R. 2016. Media Development of Science Cartoon in Subject of Magnetic Force for Fifth Grade Class of SD Negeri 1 SekarSuli. Jurnal Pendidikan Guru Sekolah Dasar Edisi 1.

Ditama, Saputro, \& Catur. 2015. Pengembangan Multimedia Interaktif dengan Menggunakan Progam Adobe Flash untuk pembelajaran Kimia Materi Hidrolisis Garam Kelas XI. Jurnal Pendidikan Kimia, Vol. 4 No. 2 ,

Ekayani, P,N. 2017. Pentingnya Penggunaan Media Pembelajaran untuk Meningkatkan Prestasi Belajar. NiluhPutuYani.Artikel.

Fitri \& Agus. 2018. Pengaruh Penggunaan Media Kartun Terhadap Kemapuan Menulis Cerita Anak. Jurnal Keilmuan dan Kependidikan Dasar, Vol. 10. No.1,

Husein, Herayanti, \& Gunawan. 2015. Pengaruh Multimedia Interaktif terhadap penguasaan konsep dan keterampilan berpikir kritis siswa pada materi Suhu dan Kalor. Jurnal Pendidikan Fisika dan Teknologi. Vol 1. No 3

Putra. I.A, \& Sujarwanto.E. 2017. Analisis Keterampilan Proses Sains Peserta Didik melalui bahan ajar Multimedia Interaktif Alat Ukur dan Pengukuran dengan Pendekatan Behavioristik. Momentum : Physics Education Journal, Vol. 1, Vol. 2, 91-102.

Sanaky. 2013. Media Pembelajaran Interaktif-Inovatif. Yogyakarta:Kaukaba. Dipantara

Setyorini. Patonah. \& Murniati. 2016. Pengembangan Media Pembelajaran Moodle, Jurnal Penelitian Pembelajaran Fisika 7. Vol.7, No.2, 156-160,

Sudiantini \& Shinta . 2018. Media Pembelajaran Terhadap Kemampuan Berpikir Kreatif, JPPM. Vol. 11. No.1.

Sugiono. 2012. Buku Metode Penelitian Kuantitatif, Kualitatif dan R\&D Alfabeta. Bandung.

Sukanta, Ahmad, \& Aisyah. 2016. Pengaruh Media Pembelajaran Film Kartun terhadap terhadap hasil belajar IPS Terpadu (Geografi) pada Materi Lingkungan Hidup dan Pelestariannya di kelas VIII SMP Negeri 1 Belitang III Kabupaten OKU Timur Tahun Pelajaran 2016/2017. Jurnal Swarnabhumi, Vol. 2, No. 1.

Tarigan, \& Siagian. 2015. Pengembangan Media Pembelajaran Interaktif pada Pembelajaran Ekonomi. Jurnal Teknologi Informasi \& Komunikasi dalam Pendidikan. Vol.2, No. 2

Yulianti, Herkulana, \& Achmadi. 2018. Pengaruh Penggunaan Media Pembelajaran terhadap hasil belajar siswa pada mata pelajaran ekonomi di SMA. Jurnal Pendidikan dan Pengajaran, Vol.4 No.1 